\title{
Two new species of Syllidae (Polychaeta) from Japan
}

\author{
$\mathrm{M}^{\mathrm{a}}$ TERESA AGUADO ${ }^{1}$, GUILLERMO SAN MARTÍN ${ }^{1}$ and EIJIROH NISHI ${ }^{2}$ \\ ${ }^{1}$ Departamento de Biología (Zoología), Facultad de Ciencias, Universidad Autónoma de Madrid, Canto Blanco, \\ 28049 Madrid, Spain. E-mail: maite.aguado@uam.es \\ ${ }^{2}$ Manazuru Marine Laboratory for Science Education, Yokohama National University, Iwa, Manazuru, \\ Kanagawa 259-0202, Japan.
}

\begin{abstract}
SUMMARY: Two new species of Japanese Syllidae (Polychaeta) belonging to the genera Haplosyllis Langerhans, 1879 and Syllis Lamarck, 1818 are described. Haplosyllis crassicirrata $\mathrm{n}$. sp. is characterized by its distinctly spindle-shaped thick dorsal cirri, with yellow granular inclusions, two unequal simple chaetae per parapodium, and the shape of the chaetae. Syllis marugani $\mathrm{n}$. sp. is characterized by its distinct orange colour (in ethanol preserved specimens), long and broad dorsal cirri, compound chaetae having robust shafts in the posterior part of the body, and short blades strongly bidentate.
\end{abstract}

Keywords: Haplosyllis, Syllis, Syllidae, polychaetes, taxonomy, systematics.

RESUMEN: Dos nuevas especies de Syllidae (Polychaeta) De JaPÓn. - Se describen dos nuevas especies de sílidos (Polychaeta) japoneses pertenecientes a los géneros Haplosyllis Langerhans, 1879 y Syllis Lamarck, 1818. Haplosyllis crassicirrata $\mathrm{n}$. sp. se caracteriza principalmente por poseer cirros anchos, fusiformes, con inclusions granulares de color amarillo en su interior, dos sedas simples desiguales por parápodo y por la forma de estas sedas. Syllis marugani n. sp. se caracteriza principalmente por poseer color naranja (en ejemplares preservados en etanol), cirros dorsales largos y anchos, y sedas compuestas con mangos robustos y angulosos en la parte posterior del cuerpo, y artejos cortos fuertemente bidentados.

Palabras clave: Haplosyllis, Syllis, Syllidae, poliquetos, taxonomía, sistemática.

\section{INTRODUCTION}

The family Syllidae is one of the most diverse families comprising about 667 valid species and 55 genera (San Martín, 2003). It is a widely distributed group found from the intertidal zone to the abyssal plains all over the world (Pleijel, 2001; Glasby, 2000); yet they are more diversified and abundant in shallow waters (San Martín, 2003).

Even though several studies and extensive monographs deal with the diversity of the syllids in Japan, complete knowledge of the group remains elusive. The earliest works on Japanese polychaetes including Syllidae species are those of Marenzeller (1879), McIntosh (1879), Moore (1903) and Izuka
(1912), the latter being a compilation of the previous works. Subsequent studies were carried out by Fauvel $(1934,1936)$, although only the first one treated syllids specifically. Subsequently, Utinomi (1956) studied syllid commensals on gorgonaceans, and Imajima and Hartman (1964) published a monograph on the polychaetous annelids of Japan that included the family Syllidae. Two years later, Imajima (1966a-f) published a series of six papers on the different subfamilies of Syllidae in which he described several new taxa. More recent works are those of Ohwada (1988), Imajima $(1997,2003)$ and San Martín and Nishi (2003). Syllids have been studied in Korea by Wui Lee and Jo Rho (1994), in China and surrounding areas by Jing and Baoling 
(1991), Fan et al. (1993), Ding and Westheide (1994, 1997), and Ding et al. (1998), and along the eastern coast of Russia (López et al., 2001).

\section{MATERIAL AND METHODS}

The specimens were found in two intertidal samples (M1 and M15), where M1 was collected on algal substrata in Manazuru Peninsula (35'10'22' N, $\left.130^{\circ} 41^{\prime} \mathrm{E}\right)$ and M15 collected on rocky shore in Yoshio, Katsuura City, Boso Peninsula (350' $\left.10^{\prime \prime} \mathrm{N}, 140^{\circ} 18^{\prime} 16^{\prime \prime} \mathrm{E}\right)$.

The samples were fixed in $10 \%$ formaldehydeseawater solution and preserved in $70 \%$ alcohol. For identification, an Olympus SZ30 stereomicroscope and Olympus $\mathrm{CH} 30$ microscope were used. Drawings were made using a drawing tube on a Nikon Optiphot microscope equipped with interference contrast optics (Nomarski). Width of specimens reported was always measured at the level of the proventricle and excluding parapodia.

The type-series are deposited in the Museo Nacional de Ciencias Naturales de Madrid (MNCNM-CSIC), Spain. Description of the morphology of the largest chaetae of Haplosyllis crassicirrata $\mathrm{n}$. sp. follows the terminology proposed by Martín et al. (2003) for species of the genus Haplosyllis (see Fig. 2A).

\section{RESULTS}

\section{Haplosyllis crassicirrata n. sp.}

(Figs. 1, 2)

Material examined: M15. Holotype MNCN 16.01/10135; Paratypes (2) MNCN 16.01/10136.

Comparative material examined: Haplosyllis basticola Sardá, Ávila and Valerie (MNCN 16.01/8439).

Etymology. The name makes reference to the thick dorsal cirri.

Description. Length of holotype $2.1 \mathrm{~mm}$ and width $0.3 \mathrm{~mm}$, for 16 chaetigers (Fig. 1A). First paratype is incomplete, length $2.4 \mathrm{~mm}$ and width $0.3 \mathrm{~mm}$, for 15 chaetigers and second paratype complete, length $1.6 \mathrm{~mm}$ and width $0.2 \mathrm{~mm}$ for 14 chaetigers. Body short, transparent and slightly yellowish. Prostomium broader than long, rectangular to oval with two pairs of small eyes in a trapezoidal arrangement. Palps broad, fused basal- ly, slightly longer than prostomium. Median antenna inserted on middle of prostomium, long, with 23-25 articles, approximately three times longer than lateral antennae. Lateral antennae inserted on anterior part of prostomium, with 8-12 articles, slightly longer than prostomium and palps together (Fig. 1A). Peristomium shorter than following segments (Figs. 1A,B). Dorsal tentacular cirri with 11-15 articles, ventral ones with 5 articles. Dorsal cirri of $1^{\text {st }}$ chaetiger longer than tentacular ones, with 20-27 articles. Subsequent cirri considerably shorter, with no more than 6 articles, without alternation in length, and considerably broader, thick, spindle-shaped, brightly and intensely coloured yellow by granular material inside. Posterior dorsal cirri decreasing in length (Fig. 1A,B). Ventral cirri oval and short, not extending beyond tips of parapodia. Two unequal simple chaetae per parapodium, one distinctly longer and wider than the other (Fig. 1E). In largest chaeta (Fig. 2A and caption), base of main fang (BMF; $2.9 \mu \mathrm{m}$ ) longer than distance between main fang upper insertion and mid-joining point between teeth (MJ; $1.3 \mu \mathrm{m}$ ); length of main fang (LMF; $1.2 \mu \mathrm{m})$ smaller than chaetal width (SW; $2.6 \mu \mathrm{m})$; upper side of main fang (US; $3.2 \mu \mathrm{m}$ ), clearly longer than lower side (LS; $1.3 \mu \mathrm{m})$. Two teeth at the tip of the chaeta, distal one clearly smaller, with a narrow angle between them. Denticles on the upper side of the main fang not seen. Small chaeta (Fig. 2B) with fang not as curved as large chaeta; both teeth at tip of chaeta similar in size and with a narrow angle between them. Denticles not present on upper side of fang. One acicula inside each parapodium, slightly leaning to one side at tip (Fig. 1D). Pygidium conical, in paratype 16.01/10136 with two short, pyriform anal cirri, similar in length to dorsal cirri, but not articulated (Figs. 1A,B). Pharynx short, extending through 2-3 segments, narrower than proventricle, provided with 10 papillae (Fig. 1C) and one small, conical distal tooth (Fig. 1B). Proventricle short and barrelshaped, similar in length to pharynx, extending through 2 segments (Figs. 1A,B).

Remarks. This new species is characterized by its small size; long and slender antennae, tentacular cirri and long dorsal cirri of $1^{\text {st }}$ chaetiger, while remaining dorsal cirri are distinctly fusiform and thick, with yellow granular inclusions. It is also distinguished by details of the chaetae. 


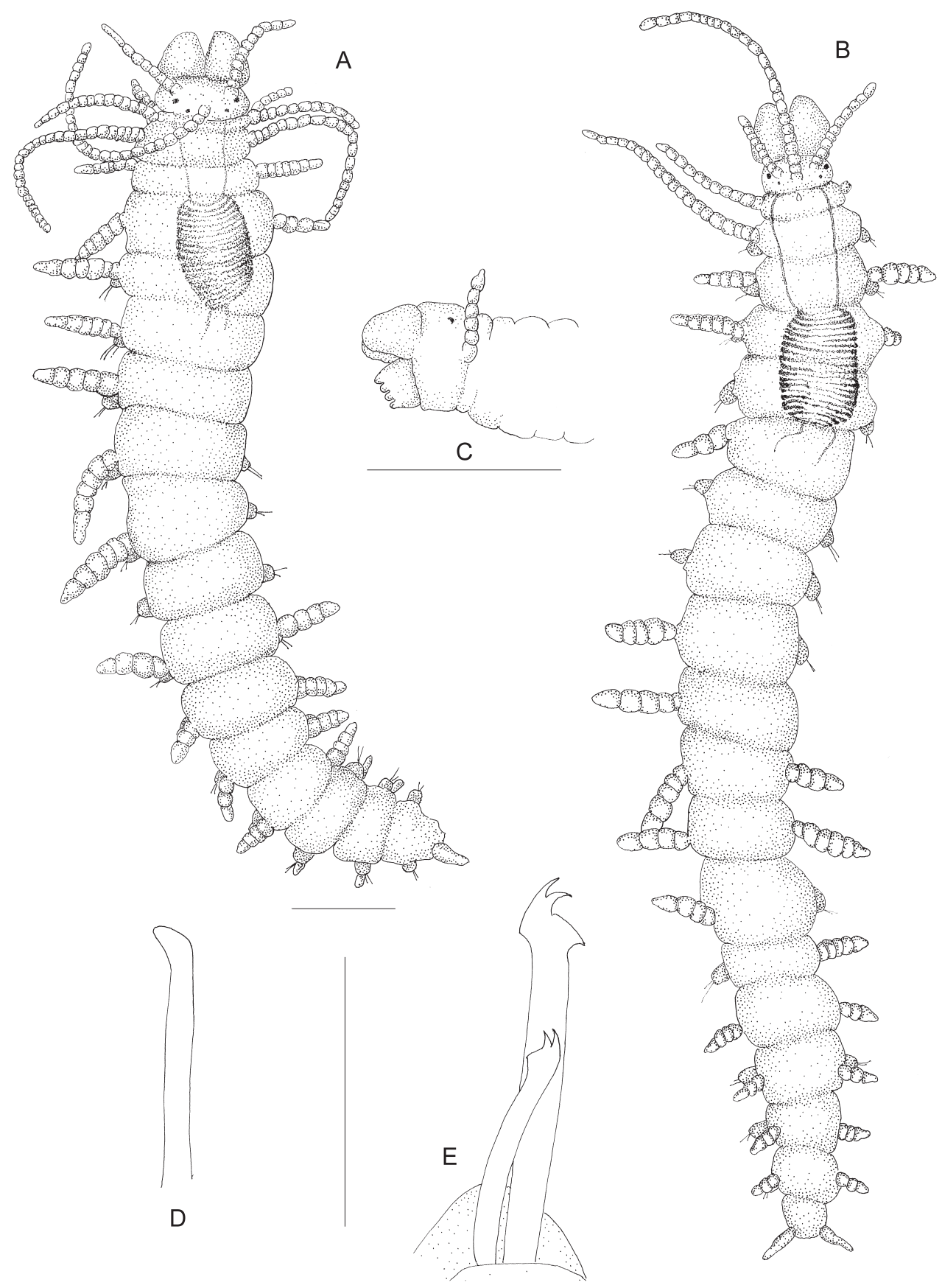

FIG. 1. - Haplosyllis crassicirrata n. sp. A: Holotype, dorsal view; B: Paratype1, dorsal view; C: Paratype 2, anterior end, lateral view; D: Acicula, midbody chaetiger; E: Simple chaetae, midbody chaetiger. Scale A-C: $0.3 \mathrm{~mm}$; D: $29 \mu \mathrm{m}$; E: $20 \mu \mathrm{m}$.

Sardá et al. (2002) distinguished two groups of Haplosyllis species using relative size, one group with taxa of small size $(2-6 \mathrm{~mm})$ and the other with taxa of larger size (more than $6 \mathrm{~mm}$ ). Haplosyllis crassicirrata clearly belongs to the group with small bodies. Probably the most similar species is Haplosyllis basticola Sardá, Ávila and Valerie, 2002, living inside the sponge Ianthella basta
(Pallas, 1776) from Micronesia. However, H. basticola has smooth and cylindrical mid-body and posterior dorsal cirri, alternating in length, and has only a single chaeta per parapodium; furthermore, the shape of the chaetae is distinctly different, the teeth at the tip and the main fang are considerably shorter and more rounded (Fig. 2C) than those found in $H$. crassicirrata. Haplosyllis anthogorgicola Utinomi, 

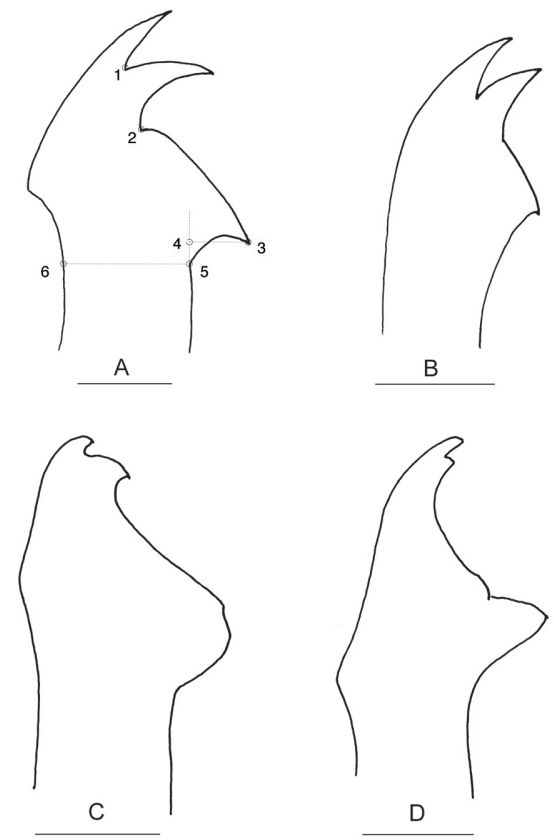

FIG. 2. - A: Large chaeta of Haplosyllis crassicirrata n. sp. Measures used to compare the chaetal profile (for largest chaeta after Martín et al. 2003); MJ (distance between 1-2), BMF (distance between 2-4), SW (6-5), LMF (distance between 3-4), US (distance between 2-3), LS (distance between 3-5). B: Small chaeta of Haplosyllis crassicirrata $\mathrm{n}$. $\mathrm{sp}$. C: Chaeta of Haplosyllis basticola (after Sardá et al., 2002); D: Chaeta of Haplosyllis anthogorgicola (after Utinomi, 1956). Scale A, B: $2 \mu \mathrm{m}$; D: $2.5 \mu \mathrm{m}$; E : $12.5 \mu \mathrm{m}$.

1956, from Japan, living on the gorgonian Anthogorgia bocki, is also similar to the new species, but differs in having cylindrical midbody dorsal cirri, a single chaeta per parapodium, and in the shape of the chaetae, where the teeth at the tip are shorter and the main fang is not curved (Fig. 2D) as in H. crassicirrata n. sp. (Utinomi, 1956; Martín et al., 2002).

Syllis marugani $\mathrm{n} . \mathrm{sp}$.

(Figs. 3, 4)

Material examined: M1. Holotype MNCN 16.01/10143 and Paratypes (3) MNCN 16.01/10144.

Etymology. This species is dedicated to Jesús Marugán for his unconditional support and his always fruitful suggestions to the first author.

Description. Holotype is a mature specimen with stolon (probably male), length for 90 chaetigers 15 $\mathrm{mm}$, width $0.9 \mathrm{~mm}$. Three paratypes, length $11 \mathrm{~mm}$ and width $0.8 \mathrm{~mm}$ for 63 chaetigers; length $8 \mathrm{~mm}$ and width $0.7 \mathrm{~mm}$ for 65 chaetigers; and length 7 $\mathrm{mm}$ and width $1 \mathrm{~mm}$ for 55 chaetigers. Body broad, thick and cylindrical, marked orange-reddish on anterior half, pigment concentrated in small spots on midbody segments becoming lighter to whitish on posterior half of body (ethanol preserved specimens). Prostomium wider than long, partially covered by peristomium, with two pairs of distinct red eyes in a trapezoidal arrangement. Median antenna arising on middle of prostomium, longer than combined length of prostomium and palps, with 16-18 broad articles; lateral antennae similar in shape and length to median one, inserted at anterior margin of prostomium, with 16-18 articles. Palps broad, slightly longer than prostomium. Peristomium similar in length to following segments, with two pairs of tentacular cirri. Dorsal tentacular cirri with 21-22 articles, ventral ones with 11-18 articles (Figs. 3A,B). Dorsal cirri long, broad, slightly longer than body width, anterior ones distinctly broad, all similar in length with about 16-22 articles (Figs. 3A, 4A). On the midbody, some cirri are longer, with 25 articles, and erect and curling over dorsum; and others slightly shorter, with 20 articles, laterally directed (Figs. $3 \mathrm{C}, 4 \mathrm{~B})$. Posterior dorsal cirri longer than those of anterior region with 25-28 articles (Fig. 4C). Ventral cirri short, not extending beyond parapodial lobes, conical on anterior chaetigers and digitiform from midbody (Figs. 4A-C). Anterior parapodia each with 13 compound, heterogomph chaetae, distal part of shafts provided with spines and bidentate blades (31-36 $\mu \mathrm{m}$ length), both teeth similar in size and length, with thin spines on margin (Fig. 4A,D). Midbody chaetigers with 12-13 compound chaetae, shafts with spines, robust and bent, with extended and curved articulation. Blades markedly short (26$28 \mu \mathrm{m}$ length), with distal tooth longer than proximal one; and about 7-8 thin spines on margin (Fig. 4B,E). Posterior parapodia with about 13 compound chaetae, with spinulate shafts more robust and distally bent than anterior ones; blades similar in length to those of midbody $(26-28 \mu \mathrm{m})$, provided with two large distal teeth, distal one longer than proximal one, and 3-5 thin, short spines on margin (Figs. 4C,F). Dorsal simple chaetae distally bifid with short subdistal spines on margin (Fig. 3G) and ventral simple chaetae distally bifid, smooth on margin (only seen in last parapodia of one paratype) (Fig. $3 F)$. Three aciculae per parapodium, slightly bent and pointed, more rounded in posterior parapodia (Figs. 4G-I). Pygidium conical, with two long articulated anal cirri, longer than pygidium and last segment together, with 15-17 articles, and one short median papilla (Fig. 3D). Pharynx extending 

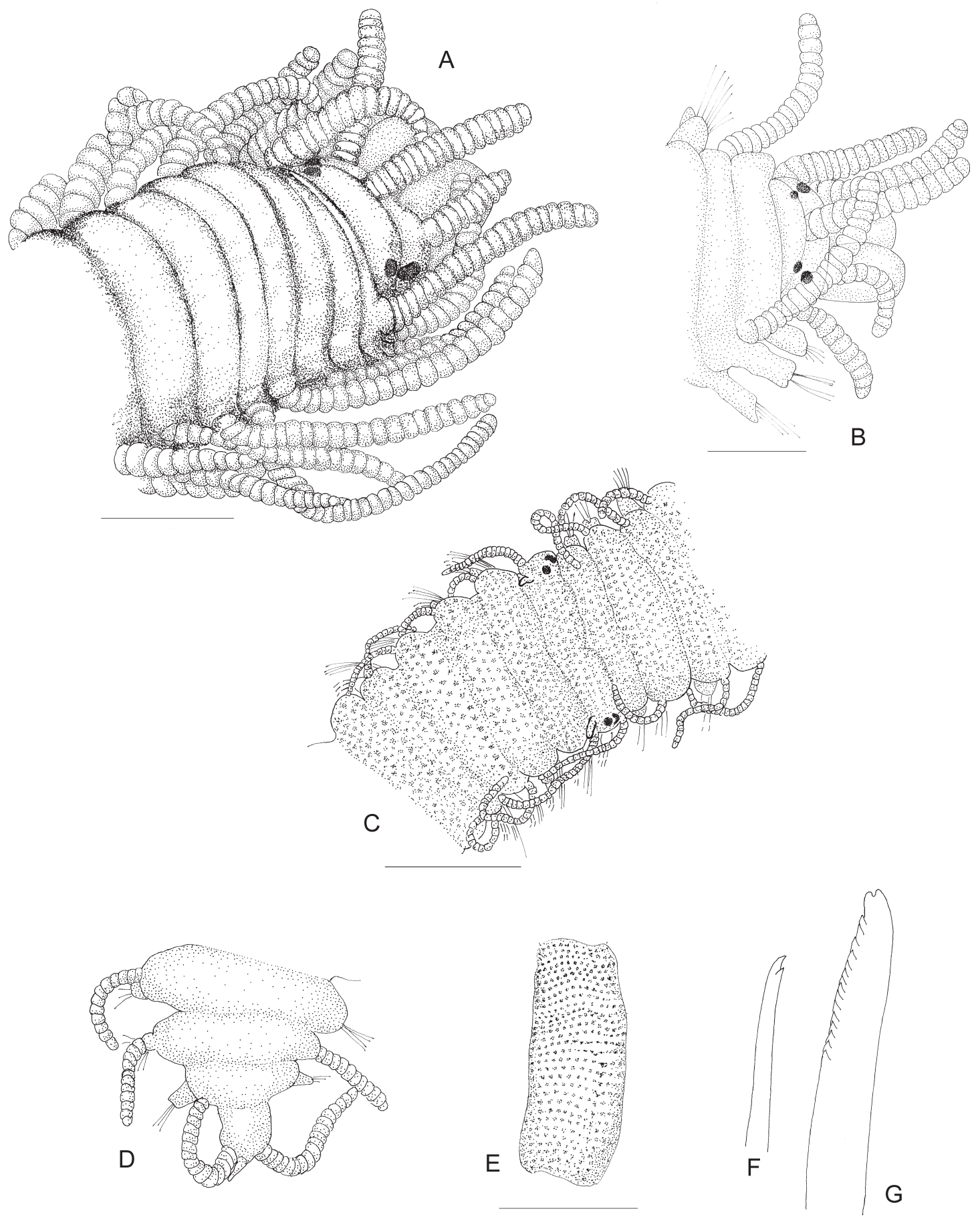

FIG. 3. - Syllis marugani n. sp. A: Holotype, anterior end, dorsal view; B: Paratype 1, anterior end, dorsal view; C: Paratype 1, attached stolon, dorsal view, anterior end; D: Paratype 2, posterior end, dorsal view; E: Proventriculus, dorsal view; F: Ventral simple chaeta, posterior chaetiger; G: Dorsal simple chaeta, posterior chaetiger. Scale A, C, E: $0.74 \mathrm{~mm}$; B: $0.38 \mathrm{~mm}$; D: $0.29 \mathrm{~mm}$.

through 9 segments; conical tooth on anterior margin. Proventricle long, extending through 8 segments, with about 38 cell-rows (Fig. 3E). Holotype and one paratype have developing stolons. Stolon of paratype (70 segments, $1.2 \mathrm{~mm}$ length), probably male, Chaetosyllis type, starts at chaetiger 52, with two small pairs of red eyes and two small lateral antennae (Fig. 3C).

Remarks. Syllis marugani $\mathrm{n}$. sp. is characterized by a markedly orange body pigmentation, thick and long dorsal cirri, and compound chaetae with short 

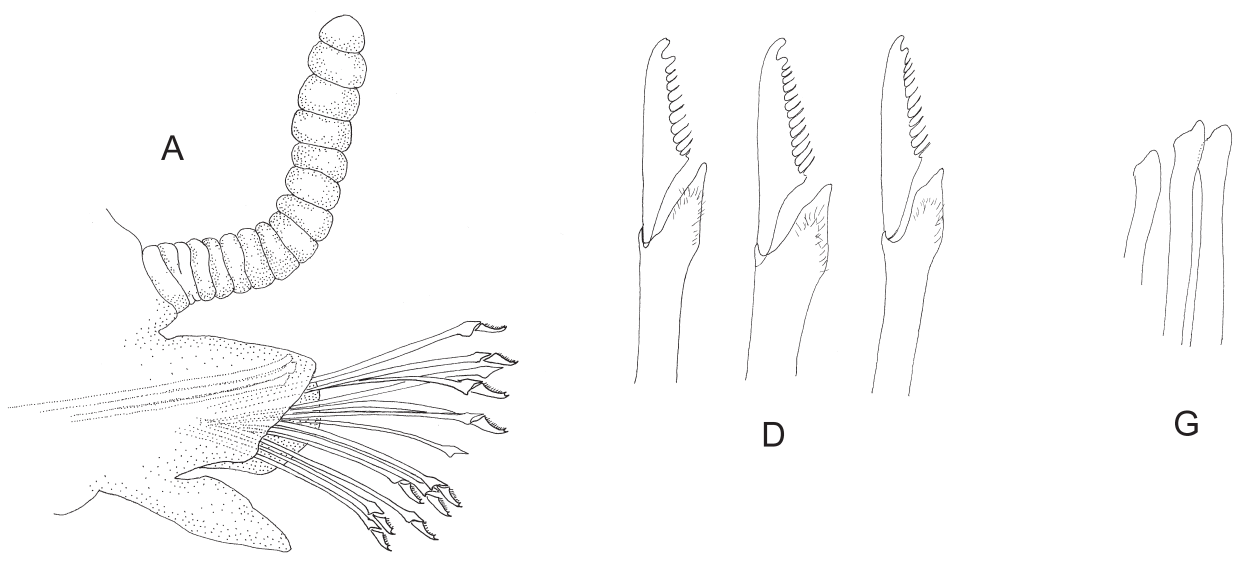

D

G
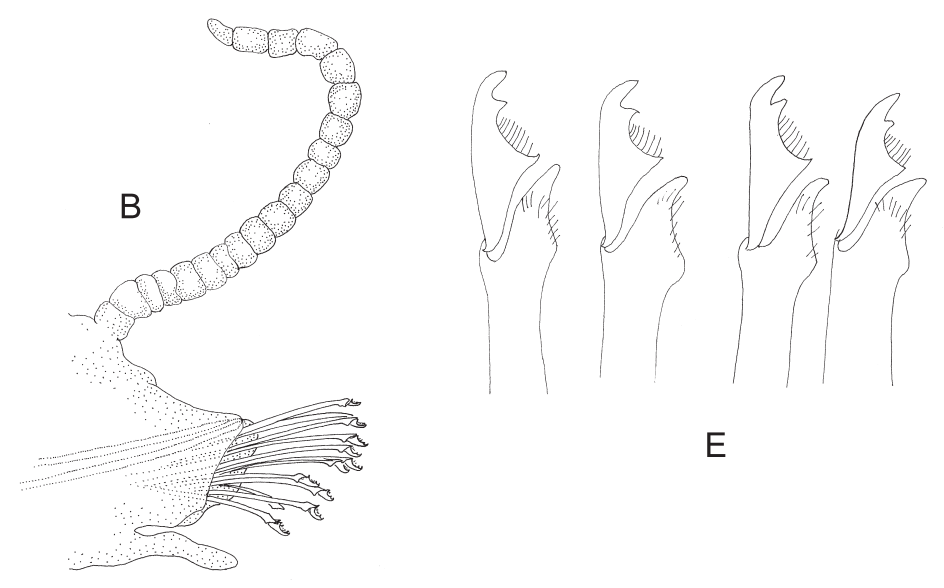

E

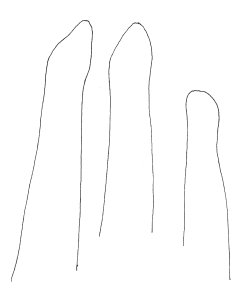

$\mathrm{H}$

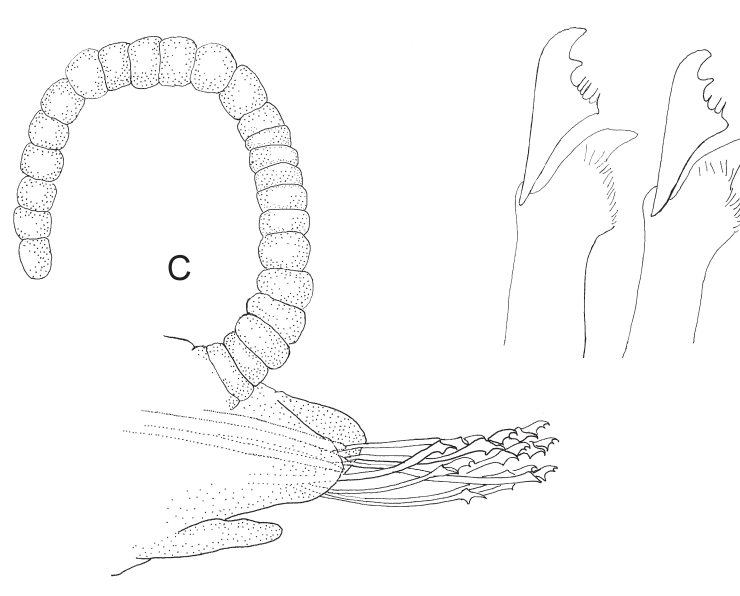

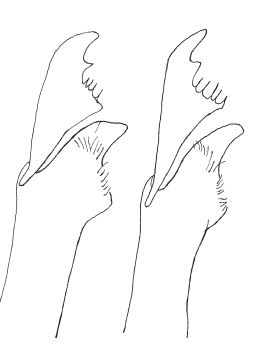

$\mathrm{F}$

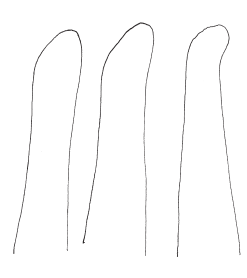

I

FIG. 4. - Syllis marugani n. sp. A: Parapodium, posterior view, anterior chaetiger; B: Parapodium, posterior view, midbody chaetiger; C. Parapodium, posterior view, posterior chaetiger; D: Compound chaetae, anterior chaetiger; E: Compound chaetae, midbody chaetiger; F: Compound chaetae, posterior chaetiger; G: Aciculae, anterior chaetiger; H: Aciculae, midbody chaetiger; I: Aciculae, posterior chaetiger. Scale A, C: $0.18 \mathrm{~mm}$; B: $0.14 \mathrm{~mm}$; D-I: $29 \mu \mathrm{m}$

bidentate blades and bent shafts on posterior part of the body. Similar species, however, do not share all of its characteristics (Table 1).

Syllis setoensis Imajima, 1966 and Syllis krohnii Ehlers, 1864 share with S. marugani the presence of broad dorsal cirri, short blades and bent posterior shafts, but the colour pattern is different, being yellow in $S$. setoensis, reddish with distinct dark red transversal lines in S. krohnii and orange in S. marugani. Some anterior dorsal cirri in $S$. setoensis and $S$. 
krohnii are broader than those in S. marugani and they have also a more distinct alternation in length and thickness. Compound chaetae in posterior chaetigers of S. krohnii are unidentate or slightly bidentate in some cases, while in S. marugani they are strongly bidentate.

Syllis monilata Imajima, 1966 has the same kind of posterior chaetae as $S$. marugani, but this species has considerably thinner dorsal cirri, alternating in length. The pigmentation of $S$. monilata is also different with a black dorsum on the first and second chaetigers.

Syllis crassicirrata (Treadwell, 1925) has thick dorsal cirri as has $S$. marugani but it differs in the colour pattern (dark dorsal bands on each segment), alternation in cirri length, shafts of compound chaetae not bent and a distinct posterior acicula, which is markedly thick, acute and protruding out of parapodial lobes.

Syllis nipponica Imajima, 1966 has broad dorsal cirri also, but pigmentation of the body is different (dorsum of 5th chaetiger is dark) and the shafts of the posterior compound chaetae are less sharpened and more curved. Syllis okadai Fauvel, 1934 has compound chaetae with thick and curved shafts in posterior chaetigers but the blades are unidentate, and the body pigmentation also differs (prostomium, palps, the first two, and the 7th to 9th chaetigers are dark chocolate coloured).

\section{ACKNOWLEDGEMENTS}

We wish to thank to our colleagues M. Capa and E. López for their comments and advice. Also special thanks to Miguel Villena (Museo Nacional de Ciencias Naturales de Madrid, MNCN) for loaned material and we are also grateful to the referees for their constructive revision. This study is a contribution of the project "Taxonomía y Sistemática de la Familia Syllidae (Polychaeta)", financiered by "Ministerio de Educación y Ciencia" of the Spanish Government, Project number CGL2005-02442.

\section{REFERENCES}

Ding, Z. and W. Westheide. - 1994. Two new interstitial Streptosyllis species from South China (Polychaeta: Syllidae). Microfauna Mar., 9: 303-312.

Ding, Z. and W. Westheide. - 1997. New records and descriptions of tidal, and subtidal syllid species (Polychaeta) from the Chinese coast. Bull. Mar. Sci., 60(2): 277-292. 
Ding, Z., F. Licher and W. Westheide. - 1998. New and newly assigned species of the genus Dentatisyllis (Polychaeta, Syllidae, Syllinae), with comments on the reproduction, together with a key and a synoptic table of all species of the genus. Sarsia, 83: 29-43.

Fan, M., Z. Ding, Z. Jing and W. Baoling. - 1993. A preliminary study on small syllids from the Huanghai Sea (Yellow Sea). J. Oceanogr. Huanghai Bohai Seas, 11(1):19-36.

Fauvel, P. - 1934. Sur Quelques Syllidiens du Japon. Annot. Zool. Jap., 14(3): 301-316.

Fauvel, P. - 1936. Annélides Polychètes du Japon. Mem. College Sci., Kyoto Imperial Univ., Series B, 12 (1): 41-92.

Glasby, C.J. - 2000. Family Syllidae. In: P.L. Beesley, G.J.B. Ross and C.J. Glasby (eds.), Polychaetes and Allies: The Southern Synthesis. Fauna of Australia. Vol. 4A Polychaeta, Myzostomida, Pogonophora, Echiura, Sipuncula. pp, 1-465 pp. CSIRO Publishing, Melbourne.

Hartmann-Schröder, G. - 1965. Zur Kenntnis der eulitoralen Polychaetenfauna von Hawaii, Palmyra und Samoa. Naturwissenschaftlichen Vereins in Hamburg, Abhandlungen und Verhandlungen Supplement, 9: 81-161.

Hartmann-Schröder, G. - 1978. Einige Sylliden-Arten (Polychaeta) von Hawai und aus dem Karibischen Meer. Mitt. Hamburg. Zool. Mus. Inst., 76: 77-218.

Imajima, M. - 1966a. The Syllidae (Polychaetous Annelids) from Japan (I). Exogoninae. Publ. Seto Mar. Biol.Lab., 13(5): 385-404.

Imajima, M. - 1966b. The Syllidae (Polychaetous Annelids) from Japan (II). Autolytinae. Publ. Seto Mar. Biol. Lab., 14(1): 27-83.

Imajima, M. - 1966c. The Syllidae (Polychaetous Annelids) from Japan (III). Eusyllinae. Publ. Seto Mar. Biol. Lab., 14(2): 85-116.

Imajima, M. - 1966d. The Syllidae (Polychaetous Annelids) from Japan (IV). Syllinae (1). Publ. Seto Mar. Biol. Lab., 14(3): 219252.

Imajima, M. - 1966e. The Syllidae (Polychaetous Annelids) from Japan (V). Syllinae (2). Publ. Seto Mar. Biol. Lab., 14(4): 253-294.

Imajima, M. - 1966f. The Syllidae (Polychaetous Annelids) from Japan (VI). Distribution and literature. Publ. Seto Mar. Biol. Lab., 14(5): 351-368.

Imajima, M. - 1997. Polychaetous Annelids of Suruga Bay, Central Japan. Nat. Sci. Mus. Monogr., 12: 149-228.

Imajima, M. - 2003. Polychaetous Annelids from Sagami Bay and Sagami Sea collected by the Emperor Showa of Japan and deposited at the Showa Memorial Institute, National Science Museum, Tokyo (II). Orders included within the Phyllodocida, Amphinomida, Spintherida and Eunicida. Nat. Sci. Mus. Monogr., 23: 1-221.

Imajima, M. and Hartman, O. - 1964. The polychaetous annelids of Japan. Allan Hancock Foundation Spec. Public., 26: 1-452.

Izuka, A. - 1912. The errantiate Polychaeta of Japan. J. College Sci., Imperial Univ., Tokyo, 30(2): 1-262.
Jing, Z. and W. Baoling. - 1991. Two new species of Exogone and Sphaerosyllis (Polychaeta, Syllidae) from the Huanghai Sea. Acta Oceanol. Sinica, 11(1): 131-137.

Licher, F. - 1999. Revision der Gattung Typosyllis Langerhans, 1879 (Polychaeta: Syllidae). Morphologie, Taxonomie und Phylogenie. Abh. senckenberg. naturforsch. Ges., 551: 1-336.

López, E., T. Britayev, D. Martín and G. San Martín. - 2001. New symbiotic associations involving Syllidae (Annelida: Polychaeta), with taxonomic and biological remarks on Pionosyllis magnifica and Syllis cf. armillaris. J. mar. biol. Ass. U.K., 81: 399-409.

Marenzeller, E. - 1879. Südjapanische Anneliden. Denkschr. Akad. Wissen. Wien (2), 41: 109-152.

Martín, D., J. Núñez, R. Riera and J. Gil. - 2002. On the associations between Haplosyllis (Polychaeta, Syllidae) and gorgonians (Cnidaria, Octocorallaria) with the description of a new species. Biol. J. Linn. Soc., 77: 455-477.

Martín, D., A.B. Temir, G. San Martín and J. Gil. - 2003. Inter-population variability and character description in the sponge-associated Haplosyllis spongicola complex (Polychaeta: Syllidae). Hydrobiologia, 496: 145-162.

McIntosh, W. C. - 1879. Report on the Annelida Polychaeta collected by H. M. S. Challenger during the years 1873-76. Challenger Rep., Zool., 12: 1-554, pls. 1-55, 1A-39A.

Moore, J. P. - 1903. Polychaeta from the Coastal Slope of Japan and from Kamchatka and Bering Sea. Proc. Acad. Nat. Sci. Philad., 55: 401-490.

Ohwada, T. - 1988. Streptospinigera alternocirrus, a new species of polychaeta (Syllidae: Eusyllinae). Proc. Biol. Soc. Wash., 101(1): 83-86.

Pleijel, F. - 2001. Syllidae, Grube, 1850. In: G.W. Rouse and F. Pleijel (eds.), Polychaetes, pp. 102-105. Oxford University Press.

San Martín, G. - 2003. Annelida, Polychaeta II: Syllidae. In: Ramos, M.A. et al. (eds.), Fauna Ibérica, vol. 21. Museo Nacional de Ciencias Naturales, CSIC, Madrid.

San Martín, G. and E. Nishi. - 2003. A new species of Alcyonosyllis Glasby and Watson, 2001 (Polychaeta: Syllidae: Syllinae) from Shimoda, Japan, commensal with gorgonian Melithaea flabellifera. Zool. Scr., 20: 371-375.

Sardá, R., C. Ávila and V.J. Paul. - 2002. An association between a syllid polychaete, Haplosyllis basticola $\mathrm{n}$. sp., and the sponge Ianthella basta. Micronesia, 34(2): 165-175.

Utinomi, H. - 1956. On the so-called "Umi-utiwa", a peculiar flabellate Gorgonacean, with notes on Syllidean Polychaete commensal. Publ. Seto Mar. Biol. Lab., 5(2): 243-250.

Wui Lee, J and B. Jo Rho. - 1994. Two new species of Syllidae (Annelida, Polychaeta) from Korea. Korean J. Sys. Zool., 10(1): 55-60.

Received September 15, 2004. Accepted May 11, 2005. 